\title{
Preparation and Characterization of St. John's Wort Herb Extracts Using Olive, Sunflower and Palm Oils
}

\author{
Ivana Arsić \\ University of Niš, Faculty of Medicine, Department of Pharmacy, Niš, Serbia
}

\section{SUMMARY}

The aim of the study was to obtain St. John's wort herb extract (drug:extract ratio 1:5), in a traditional way, using different solvents (sunflower, olive and palm oils) with or without antioxidants $(0,02 \%$ alpha-tocopherol and $0,01 \%$ butylhydroxyanisol). Their characterization was done (organoleptic features, relative density, refractive index, acid number) immediately after the preparation, and during the period of 12 months (the samples were stored at room temperature, $\left.22 \pm 2^{\circ} \mathrm{C}\right)$.

The type of oil used for the extraction of St. John's wort herb has a significant influence on organoleptic and physicochemical characteristics of extracts. Oil extracts had approximately the same values for refractive index and relative density as solvents used for extraction. The acid numbers of extracts were slightly higher compared to the used oils. Using the antioxidants for preparing the St. John's wort oil liquid herb extracts did not change the acid number of extracts made using sunflower and palm oils, while oil extracts made using olive oil and tocopherol or BHA had lower acid number values. During the period of 12 months, only extracts which were made using three different vegetable oils, with the use of antioxidants, showed satisfactory physicochemical, chemical and microbiological stability (with no significant changes in organoleptic properties, relative density, refractive index, acid number value and microbiological safety), which points to the necessity of using antioxidants in the preparation of St. John's wort oil herb extracts, using the traditional method.

Key words: St. John's wort herb, oil extracts, sunflower, olive and palm oils 


\section{INTRODUCTION}

St. John's wort (Hypericum perforatum L., Hypericaceae) is a perennial herbaceous plant with spindle-shaped and branched root. The flowering tops of this plant - Hypericiherba are used in medicine. St. John's Wort has a complex chemical composition. According to the European Pharmacopoeia 8.0 (1), it consists of a large number of different secondary metabolites: naphthodianthrone (from 0.06 to $0.4 \%$ ), derivatives of phloroglucinols $(0.2-4 \%)$, flavonoids (2$4 \%$, biflavonoids, flavonoid glycosides, essentialoil (0.1-0.25\%), a small amount of chlorogenic acid, the caffeic acid, 3-O-caffeoylquinic acid, 3,4,5-O-three caffeoylquinic acid and 1,3,5-O-three caffeoylquinic acid. The most important constituents, phloroglucinols, flavonoids and naphthodianthrone are responsible for the pharmacological effects (1).

The European Pharmacopoeia describes the St. John's wort herb, starting from the $3^{\text {rd }}$ edition (European Pharmacopoeia 3.0) (2). According to the monograph of the European Pharmacopoeia 8.0, the content of total naftodiantrons expressed as hypericin should be at least $0.08 \%$. The Ph. Eur. 8.0 lists the monograph of quantified St. John's wort dry herb extract (Hyperici herbae extractum siccum quantificatum).

St. John's wort belongs to the group of plants whose folk names point to the healing properties (plants that people had linked to the Virgin Mary are usually helpful with gynecological diseases, irregular menstruations, ovarian inflammations, etc.). Or grass of St. John, as it is called in the United Kingdom (St. John's Wort) (3). In the middle ages, St. John's wort was attributed the protective power from evil spirits. It was believed to have special powers, when harvested at Midsummer. This plant was placed in amulets because it was safe against witches (4).

In folk medicine, St. John's wort is used orally for the treatment of depressive disorders, anxiety, mental distress, bronchitis, asthma, ulcers, gallbladder diseases, gastritis, diarrhea, headaches, gout, rheumatism. Topical administration of oil extract (Oleum Hyperici) of this plant is used for wound healing (especially wounds from burns and injuries), for the treatment of skin ulcers and hemorrhoids (5). St. John's wort oil has traditionally been used orally for the treatment of digestive disorders, complaints with stomach and ulcers (recommended dosage is one teaspoon of oil extract on an empty stomach in the morning and in the evening) (6-8).
St. John's Wort oil herb extract (Hyperici herbae extractum oleosum) is prepared by maceration of fresh flowering tops of St. John's Wort with olive oil, palm oil or wheat-germ oil exposed to sunlight for 40 days. The method for oil extract preparation have been described in the supplement of German Pharmacopoeia (DAB, 1953): fresh or dry flowering tops of St. John's Wort are poured into vegetable oil (olive, sunflower or other; drug:oil ratio 1:4), in a glass bowl and left in a warm place for fermentation. Water was removed from the extract with sodium sulfate and then the extraction was continuously exposed to sunlight for a period of 4-6 weeks.

The Swiss Pharmacopoeia (Pharmacopoeia Helvetica, 8th edition, 1997)(9) lists the monograph of St. John's wort oil and describes its preparation by maceration of fresh flowering tops of St. John's wort with olive or sunflower oil exposed to sunlight for a period of 2-3 weeks.

In Serbia, St. John's wort oil is traditionally prepared by maceration of fresh flowering tops with sunflower oil (drug:extract ratio 1:5) exposed to sunlight for 40 days. This is perhaps the most commonly used drug in our folk medicine (10).

Commission E approved the topical application of Oleum Hyperici for the treatment of injuries, firstdegree burns and myalgia (St. John's wort oil herb extract is prepared by maceration with olive oil or wheat-germ oil for few weeks) (11).

Data concerning the chemical composition of St. John's oil are different, probably due to the different geographical origin of the plant material, different growing conditions, time of harvesting, using the raw or dried plant material for extraction, lipophility of oil used for extraction, duration of exposure to sunlight, storage conditions $(12,13)$. Although the St. John's wort oil herb extract is used very often, there are not enough stability and quality data.

The aim of the study was to obtain St. John's wort herb extract (drug:extract ratio 1:5), using different solvents (sunflower, olive and palm oil) with or without antioxidants (alpha-tocopherol and butylhydroxyanisol-BHA). Their characterization was done (organoleptic features, relative density, refractive index, acid number) immediately after preparation, and during the period of 12 months (the samples were stored at room temperature and were characterized after 3, 6 and 12 months). 


\section{MATERIALS AND METHODS}

\section{Materials}

Samples of Hypericum perforatum L. were collected on the Rtanj mountain, Serbia, during the flowering period, at the end of June 2009 and has been identified at the Institute for Medicinal Plant Research "Dr Josif Pančić" in Belgrade.

As extraction solvents we used the following oils: palm oil (PO), purchased from Forli, Italy; olive oil (OO), from Jan Dekker, The Netherlands and sunflower oil (SO) from Sunce, Sombor (Serbia).

As antioxidants we used: butylhydroxyanisolBHA(Triveni Chemicals, India) and tocopherol (D,L$\alpha$-tocopherol- BASF, Germany).

\section{Methods}

\section{Preparation of oil extracts}

Three St. John's wort oil herb extracts were prepared according to the prescriptions from traditional medicine, by maceration in three different extraction solvents: olive oil (OO-E), palm oil (PO-E) and sunflower oil (SO-E). Beside the extracts without antioxidants, there were prepared extracts with the same extraction solvents with addition of $0.02 \%$ alpha-tocopherol and marked with: OO-ET, PO-ET and SO-ET, as well as with the addition of $0.01 \%$ of $\mathrm{BHA}$ and marked with: OO-EB, POEB and SO-EB.

Preparation of the extracts without antioxidants: extracts were prepared by maceration of $100 \mathrm{~g}$ of fresh flowering tops of St. John's Wort in 2L laboratory glass, with $550 \mathrm{~g}$ of different oils (olive oil, palm oil and sunflower oil) exposed to sunlight for 40 days (according to the prescriptions from Ph. Hel. 1997 and DAB 1957). After this period, the drug leaks through the triple gauze, being thus separated from the liquid. Extraction solvent was added in an amount necessary to produce a $500 \mathrm{~g}$ of extract (drug:extract ratio-D:E was 1:5) (MF 2008). Prepared extracts were kept in dark glass bottles, at room temperature $\left(22+2^{\circ} \mathrm{C}\right)$.

Preparation of the extracts with antioxidants was carried out in the same way - drug was poured into extraction solvents in which the previously adequate amount of antioxidants was dissolved.

\section{Characterization of oil extracts and testing their physicochemical and microbiological stability}

Organoleptic appearance, refractive index, relative density, acid number and microbiological quality in samples which were kept in dark glass bottles, were determined after the preparation and after 3, 6 and 12 months (storage temperature of samples was $22 \pm 2^{\circ} \mathrm{C}$ ), in order to establish physical, chemical and microbiological stability.

Microbiological quality of the extracts was determined using the procedure listed in pharmacopoeia (Ph. Eur. 7.0) - 5.1.8. - Microbiological Quality of Herbal Medicinal products for oral use (13).

\section{RESULTS AND DISCUSSION}

St. John's wort herb extracts prepared using olive and sunflower oil, immediately after preparation were intense red colored, bright, with specific pleasant odor, whereas the extracts obtained using the palm oil were slightly opalescent at room temperature and with a very mild odor (Table 1). 
Table 1. Characteristics of St. John's wort oil extracts after preparation

\begin{tabular}{cccccc}
\hline \hline Samples & Appearance & $\begin{array}{c}\text { Refractive } \\
\text { index }\end{array}$ & $\begin{array}{c}\text { Relative } \\
\text { density }\left(\mathrm{g} / \mathrm{cm}^{2}\right)\end{array}$ & $\begin{array}{c}\text { Acid } \\
\text { number }\end{array}$ & $\begin{array}{c}\text { Microbiological } \\
\text { quality }\end{array}$ \\
\hline OO-E & $\begin{array}{c}\text { Clear, red liquid with } \\
\text { characteristic odor }\end{array}$ & 1,4691 & 0,915 & 0,37 & + \\
\hline PO-E & $\begin{array}{c}\text { Turbid, red liquidwith } \\
\text { characteristic, mild odor }\end{array}$ & 1,4635 & 0,87 & 0,05 & + \\
\hline SO-E & $\begin{array}{c}\text { Clear, red liquid with } \\
\text { characteristic odor }\end{array}$ & 1,472 & 0,925 & 1 & + \\
\hline OO-ET & $\begin{array}{c}\text { Clear, red liquid with } \\
\text { characteristic odor }\end{array}$ & 1,4691 & 0,915 & 0,27 & + \\
\hline PO-ET & $\begin{array}{c}\text { Turbid, red liquid with } \\
\text { characteristic, mild odor }\end{array}$ & 1,4635 & 0,87 & 0,05 & + \\
\hline SO-ET & $\begin{array}{c}\text { Clear, red liquid with } \\
\text { characteristic odor }\end{array}$ & 1,472 & 0,927 & 1 & + \\
\hline OO-EB & $\begin{array}{c}\text { Clear, red liquid with } \\
\text { characteristic odor }\end{array}$ & 1,469 & 0,915 & 0,31 & + \\
\hline PO-EB & $\begin{array}{c}\text { Turbid, red liquid with } \\
\text { characteristic, mild odor }\end{array}$ & 1,4635 & 0,87 & 0,05 & + \\
\hline SO-EB & $\begin{array}{c}\text { Clear, red liquid with } \\
\text { characteristic odor }\end{array}$ & 1,4725 & 0,927 & 1 & + \\
\hline \hline
\end{tabular}

+ microbiological quality (Ph. Eur. 7.0)

Oil extracts had approximately the same values of refractive index and relative density, as solvents used for extraction. The acid number of extracts was slightly higher compared to the used oil, which was due to the influence of sunlight to which they were exposed during extraction (high temperature leads to hydrolysis of triglycerides and production of free fatty acids) (Table 1). The acid number of extract PO-E was the lowest in comparison to the other extracts (in accordance with the low values of the acid number of palm oil), indicating a lower level of free fatty acid in palm oil (Table 1). Palm oil was included in the examination for its stability at higher temperature (it is extensively used in the food industry, e.g. for frying), because the St. John's Wort oil was obtained by exposing the extraction mixture to sunlight.

Using the antioxidants for prepration of herb St. John's wort oil liquid herb extracts did not affect the acid number value of extracts made using sunflower and palm oil, while oil extracts made using olive oil and tocopherol or BHA had lower acid numbers values.

Oxidation processes are the main reason for oil deterioration. They lead to the chemical changes that affect the organoleptic properties of oil (formation of peroxide), which with further oxidation provide different carbonyl compounds (epihidrin aldehyde, heptyl aldehyde, nonyl aldehyde). Factors affecting the formation of peroxide are: light intensity, temperature, oxygen, free fatty acids and the presence of certain metal ions which act as catalysts $(3,14)$. Because of that, determining the peroxide number of oils and oil extracts was supposed to be a parameter that allows monitoring of the stability of St. John's wort oil herb extracts. However, using the method described in pharmacopoeia, it was not possible to determine the peroxide number of St. John's wort oil herb liquid extracts for two reasons: because of the extract color it was difficult to accurately determine the moment when color changes and because the active substances of extracts react with sodium thiosulfate. This was established when the peroxide number of the oil extract was determined, and then certain amount of dry extract of St. John's wort was dissolved in this sample, after which the peroxide number was measured again. The difference in the value of the peroxide number before and after the dissolution of a dry extract was very high (5-7 units) and indicated that certain amount of the reagent for determining (sodium thiosulfate) was "spent" for some other chemical reaction, and not only in the process of determining the peroxide number (reaction between sodium thiosulfate and iodine in the presence of starch as an indicator). 
Considering the fact that extracts OO-E, PO-E and SU-E did not contain an antioxidant and that other extracts contain $0.02 \%$ of alpha-tocopherol, or BHA $0.01 \%$, by monitoring the stability of the extracts, the influence of antioxidants on the stability of oily extracts was determined.
Three months after preparation, there were insignificant changes in the observed parameters of oil extracts (Table 2). An increase in the acid number value in SO-E was registered (for 0.25 units) as well as the increasing intensity of the odor of PO-E and OO-E. Extracts with antioxidants have not changed organoleptic nor physicochemical properties.

Table 2. Characteristicsof St. John's wort oil extracts after 3 months (samples stored at $22 \pm 2{ }^{\circ} \mathrm{C}$ )

\begin{tabular}{cccccc}
\hline \hline Samples & Appearance & $\begin{array}{c}\text { Refractive } \\
\text { index }\end{array}$ & $\begin{array}{c}\text { Relative } \\
\text { density } \\
\left(\mathrm{g} / \mathrm{cm}^{2}\right)\end{array}$ & Acid number & $\begin{array}{c}\text { Microbiological } \\
\text { quality }\end{array}$ \\
\hline OO-E & $\begin{array}{c}\text { Clear, red liquid with } \\
\text { characteristic odor }\end{array}$ & 1,4693 & 0,915 & 0,37 & + \\
\hline PO-E & $\begin{array}{c}\text { Turbid, red liquidwith } \\
\text { characteristic, mild odor }\end{array}$ & 1,4635 & 0,87 & 0,05 & + \\
\hline SO-E & $\begin{array}{c}\text { Clear, red liquid with } \\
\text { characteristic odor }\end{array}$ & 1,472 & 0,925 & 1,25 & + \\
\hline OO-ET & $\begin{array}{c}\text { Clear, red liquid with } \\
\text { characteristic odor }\end{array}$ & 1,467 & 0,915 & 0,27 & + \\
\hline PO-ET & $\begin{array}{c}\text { Turbid, red liquidwith } \\
\text { characteristic, mild odor }\end{array}$ & 1,4635 & 0,87 & 0,05 & + \\
\hline SO-ET & $\begin{array}{c}\text { Clear, red liquid with } \\
\text { characteristic odor }\end{array}$ & 1,472 & 0,927 & 1 & + \\
\hline OO-EB & $\begin{array}{c}\text { Clear, red liquid with } \\
\text { characteristic odor }\end{array}$ & 1,469 & 0,915 & 0,31 & + \\
\hline PO-EB & $\begin{array}{c}\text { Turbid, red liquidwith } \\
\text { characteristic, mild odor }\end{array}$ & 1,4635 & 0,87 & 0,05 & + \\
\hline SO-EB & $\begin{array}{c}\text { Clear, red liquid with } \\
\text { characteristic odor }\end{array}$ & 1,472 & 0,927 & 1 & + \\
\hline \hline
\end{tabular}

+ microbiological quality (Ph. Eur. 7.0)

Six months after preparation, extracts without antioxidants changed their odor, which was rancid (SOE), probably due to oxidation process of unsaturated fatty acids in the extract (Table 3). The acid number of this oil extracts changed significantly compared to the value after preparation (from value 1 after the preparation to value 2 after 6 months of storage at $22+2$ $\left.{ }^{\circ} \mathrm{C}\right)$.

Physicochemical and organoleptic changes of oil extracts were intensified during the period of 6-12 months of storage at room temperature. After a year, SO-E had an intense odor of rancid oil, with an acid number value 3 , and it was the least stable oil extract from all others prepared (Table 4).

Extracts which were made using sunflower oil were the least stable, i.e. they had the fastest changing of organoleptic and physicochemical characteristics (compared to the extracts without antioxidants). Extracts with palm oil were the most stable extracts in this respect. The problem might be caused by its consistency, especially with the pouring from bottles (it should be used after heating at a temperature of $25^{\circ} \mathrm{C}$ ).

All tests show the positive influence of antioxidants on the stability of the used St. John's wort oil herb extracts. Both antioxidants had almost the same impact on the organoleptic characteristics and the acid number value of prepared oil extracts (when we chose the antioxidants for preparing of St. John's wort oil herb liquid extracts we had on mind that alpha-tocopherol, as a viscous liquid, was easily soluble in oils, but BHA was significantly cheaper) (14). 
Table 3. Characteristics of St. John's wort oil extracts after 6 months (samples stored at $22 \pm 2{ }^{\circ} \mathrm{C}$ )

\begin{tabular}{|c|c|c|c|c|c|}
\hline Samples & Appearance & $\begin{array}{c}\text { Refractive } \\
\text { index }\end{array}$ & $\begin{array}{l}\text { Relative } \\
\text { density } \\
\left(\mathrm{g} / \mathrm{cm}^{2}\right)\end{array}$ & Acid number & $\begin{array}{c}\text { Microbiological } \\
\text { quality }\end{array}$ \\
\hline OO-E & $\begin{array}{c}\text { Clear, red liquid with } \\
\text { intensive odor }\end{array}$ & 1,4693 & 0,915 & 0,37 & + \\
\hline PO-E & $\begin{array}{l}\text { Turbid, red liquidwith } \\
\text { characteristic, mild odor }\end{array}$ & 1,4635 & 0,87 & 0,05 & + \\
\hline SO-E & $\begin{array}{l}\text { Clear, red liquid with } \\
\text { intensive „rancid“odor }\end{array}$ & 1,472 & 0,925 & 2 & + \\
\hline OO-ET & $\begin{array}{c}\text { Clear, red liquid with } \\
\text { characteristic odor }\end{array}$ & 1,467 & 0,915 & 0,27 & + \\
\hline PO-ET & $\begin{array}{l}\text { Turbid, red liquid with } \\
\text { characteristic, mild odor }\end{array}$ & 1,4635 & 0,87 & 0,05 & + \\
\hline SO-ET & $\begin{array}{l}\text { Clear, red liquid with } \\
\text { characteristic odor }\end{array}$ & 1,472 & 0,927 & 1 & + \\
\hline OO-EB & $\begin{array}{l}\text { Clear, red liquid with } \\
\text { characteristic odor }\end{array}$ & 1,4690 & 0,915 & 0,31 & + \\
\hline PO-EB & $\begin{array}{l}\text { Turbid, red liquid with } \\
\text { characteristic, mild odor }\end{array}$ & 1,4635 & 0,87 & 0,05 & + \\
\hline SO-EB & $\begin{array}{l}\text { Clear, red liquid with } \\
\text { characteristic odor }\end{array}$ & 1,472 & 0,927 & 1 & + \\
\hline
\end{tabular}

Table 4. Characteristics of St. John's wort oil extracts after 12 months (samples stored at $22 \pm 2{ }^{\circ} \mathrm{C}$ )

\begin{tabular}{|c|c|c|c|c|c|}
\hline Samples & Appearance & $\begin{array}{l}\text { Refractive } \\
\text { index }\end{array}$ & $\begin{array}{l}\text { Relative } \\
\text { density } \\
\left(\mathrm{g} / \mathrm{cm}^{2}\right)\end{array}$ & Acid number & $\begin{array}{c}\text { Microbiological } \\
\text { quality }\end{array}$ \\
\hline OO-E & $\begin{array}{l}\text { Clear, red liquid with } \\
\text { mild,,rancid“odor }\end{array}$ & 1,4693 & 0,915 & 0,55 & + \\
\hline PO-E & $\begin{array}{l}\text { Turbid, red liquidwith } \\
\text { characteristic odor }\end{array}$ & 1,462 & 0,865 & 0,05 & + \\
\hline SO-E & $\begin{array}{l}\text { Clear, red liquid with } \\
\text { intensive „rancid“odor }\end{array}$ & 1,472 & 0,925 & 3,5 & + \\
\hline OO-ET & $\begin{array}{l}\text { Clear, red liquid with } \\
\text { characteristic odor }\end{array}$ & 1,467 & 0,915 & 0,47 & + \\
\hline PO-ET & $\begin{array}{l}\text { Turbid, red liquidwith } \\
\text { characteristic odor }\end{array}$ & 1,4635 & 0,87 & 0,05 & + \\
\hline SO-ET & $\begin{array}{l}\text { Clear, red liquid with } \\
\text { characteristic odor }\end{array}$ & 1,472 & 0,927 & 1,5 & + \\
\hline OO-EB & $\begin{array}{l}\text { Clear, red liquid with } \\
\text { characteristic odor }\end{array}$ & 1,466 & 0,915 & 0,35 & + \\
\hline PO-EB & $\begin{array}{l}\text { Turbid, red liquid with } \\
\text { characteristic odor }\end{array}$ & 1,4635 & 0,87 & 0,05 & + \\
\hline SO-EB & $\begin{array}{l}\text { Clear, red liquid with } \\
\text { characteristic odor }\end{array}$ & 1,472 & 0,927 & 1 & + \\
\hline
\end{tabular}

+ microbiological quality (Ph. Eur. 7.0) 


\section{CONCLUSIONS}

St. John's wort oil herb extracts were prepared by the maceration method using three different vegetable oils; drug extract ratio was 1:5. The type of oil used for the extraction of St. John's wort herb has a significant influence on the content of active substances in the extracts and on their organoleptic and physicochemical characteristics. St. John's wort herb extracts prepared using olive and sunflower oil immediately after preparation were of intense red color, bright, with specific pleasant odor, whereas the extracts obtained using the palm oil were slightly opalescent at room temperature and with a very mild odor. Oil extracts had approximately the same values for refractive index and relative density, as solvents used for extraction. The acid number of extracts was slightly higher compared to the used oils. Using the antioxidants for preparing the St. John's wort oil liquid herb extracts did not change the acid number value of extracts made using the sunflower and palm oils, while oil extracts made using olive oil and tocopherol or BHA had lower acid number values. Three months after preparation, there were insignificant changes in the observed parameters of oil extracts. Six months after the preparation, extracts without antioxidants changed their odor, which was rancid (SOE), probably due to oxidation process of unsaturated fatty acids in the extract. Physicochemical and organoleptic changes of oil extracts were intensified during the period of 6-12 months of storage at room temperature. During the period of 12 months, the extracts which were made using three different vegetable oils, with antioxidants (alpha-tocopherol or BHA), showed satisfactory physicochemical, chemical and microbiological stability (with no significant changes in the organoleptic properties, relative density, refractive index, acid number value and microbiological safety), which points to the necessity of using antioxidants in the preparation of St. John's wort oil herb extracts, using the traditional method.

\section{References}

1. The European Pharmacopoeia, 8th edition (Ph. Eur. 8.0) Strasbourg: Council of Europe, 2014.

2. The European Pharmacopoeia, 3th edition (Ph. Eur. 3.0) Strasbourg: Council of Europe, 1999.

3. Mišan A., Arsić I., Đorđević S, Tadić V, Psodorov Đ. Funkcionalna hrana i lekovito bilje, Naučni institut za prehrambene tehnologije, Novi Sad, 2013.

4. Čajkanović V. Rečnik srpskih narodnih verovanja o biljkama. Srpska književna zadruga, Beograd, 1985.

5. Gruenwald J., Brendler T., Jaenicke C. PDR for Herbal Medicines. Montevale: Medical Economics Company; 2004.

6. Wichtl M. Herbal Drugs and Phytopharmaceuticals. Medpharm scientific publishers, Stuttgart, 2004.

7. Blumental M. St. John's Wort U: The complete German Commisson E Monographs, Terapeutic guide in Herbal medicine, 1999.

8. Weiss RF., Fintelmann V. Herbal Medicines. Stuttgart: Georg Thieme Verlag; 2000.
9. Pharmacopoeia Helvetica 8th edition, Bern, Department federal de I'nterieur, 1997.

10. Tucakov J. Lečenje bijem. Rad; Beograd: 1996.

11. Wolfle U., Seellinger G., Schempp C.M. Topical Application of St. John's Wort (Hypericum perforatum), Planta Med 2014; 80: 109-20.

12. Arsić I, Žugić A, Runjaić Antić D., Zdunić G., Dekanski D., Marković G., Tadić V. Hypericum Perforatum L. Hypericaceae/Guttiferae Sunflower, Olive and Palm Oil Extracts Attenuate Cold Restraint Stress-Induced Gastric Lesions. Molecules, 2010; 15: 6688-98. http://dx.doi.org/10.3390/molecules15106688

13. The European Pharmacopoeia, 7th edition (Ph. Eur. 7.0) Strasbourg: Council of Europe, 2010.

14. Arsić I. Preparations with St. John's wort oil extracts: formulations, and evaluation of their stability and efficacy. Expert thesis. Faculty of Pharmacy, Belgrade, 2015. 


\title{
Priprema i karakterizacija ekstrakata herbe kantariona korišćenjem maslinovog, suncokretovog i palminog ulja
}

\author{
Ivana Arsić \\ Univerzitet $u$ Nišu, Medicinski fakultet, Odsek za farmaciju, Niš, Srbija
}

\section{SAŽETAK}

Cilj rada bio je izrada tečnih uljanih ekstrakata herbe kantariona (odnos droga:ekstrakt=1:5) tradicionalnim postupkom korišćenjem različitih rastvarača za ekstrakciju (maslinovo ulje-MU, suncokretovo ulje-SU i palmino ulje-PU), bez ili sa antioksidansom $(0,02 \%$ alfa-tokoferolaili $0,01 \%$ butilhidroksianizola). Izvršena je njihova karakterizacija (ispitivanje organoleptičkihkarakteristika, relativne gustine, indeksa refrakcije, kiselinskog broja i mikrobiološkogkvaliteta) nakon izrade i u periodu od 12 meseci čuvanja (karakterizacija vršena nakon 3,6 i 12 meseci) na sobnoj temperaturi $\left(22 \pm 2^{\circ} \mathrm{C}\right)$.

Vrsta ulja korišćenog za ekstrakciju imala je uticaj na organoleptičke i fizičko-hemijske karakteristike izrađenih ekstrakata. Uljani ekstrakti su nakon izrade imali približno jednake vrednosti indeksa refrakcije i relativne gustine kao ekstragensi korišćeni u procesu ekstrakcije. Kiselinski brojevi ekstrakata bili su nešto viši u poređenju sa uljima od kojih su izrađeni, što se može objasniti uticajem sunčevog zračenja kojem su bili izloženi tokom procesa ekstrakcije (povišena temperatura dovodi do hidrolize triglicerida i oslobađanja slobodnih masnih kiselina). Upotreba antioksidanasa u izradi tečnih, uljanih ekstrakata herbe kantariona nije imala uticaja na vrednost kiselinskog broja ekstrakata izrađenih uz korišćenje suncokretovog $i$ palminog ulja, dok se upotrebom tokoferola, odnosno BHA kod maslinovog ulja, kao sredstva za ekstrakciju dobijaju ekstrakti niže vrednosti kiselinskog broja. U periodu od 12 meseci čuvanja na sobnoj temperaturi, samo su uljani ekstrakti izrađeni uz korišćenje antioksidansa (tokoferol ili BHA) pokazali zadovoljavajuću organoleptičku, fizičko-hemijsku i mikrobiološku stabilnost, što ukazuje na neophodnost korišćenja antioksidanasa $u$ izradi tečnih, uljanih ekstrakata herbe kantariona tradicionalnim postupkom izrade.

Ključne reči: herba kantariona, uljani ekstrakti, suncokretovo, maslinovo i palmino ulje 